\title{
RETHINKING SOCIO-ECONOMIC RIGHTS IN THE SOUTH AFRICAN CONSTITUTIONAL FRAMEWORK FROM THE PERSPECTIVE OF HUMAN AGENCY: REFLECTIONS OF A LAW STUDENT
}

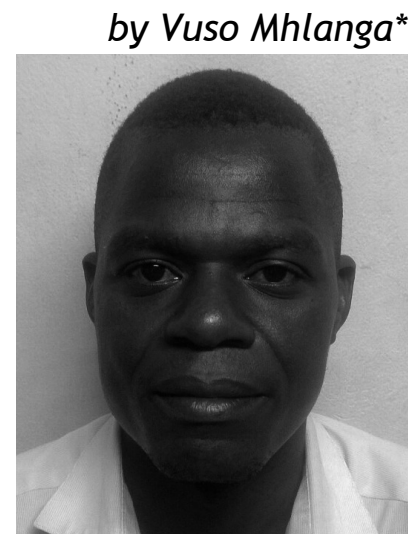

Improve the quality of life of all citizens and free the potential of each person ...

The South African Constitution is different: it retains from the past only what is defensible and represents a decisive break from, and a ringing rejection of that part which is disgracefully racist, authoritarian, insular, and repressive ...

* Third year LLB student in the University of South Africa's College of Law and Bachelor of Arts Honours Degree in English. The article seeks to reconceptualise Socio-Economic Rights in the South African Constitutional Scheme from the ideologically - laden concept of human agency. The article's philosophical grounding challenges deeply-embedded uneven power structures in the South African society and advocates for a transformative jurisprudence which unlocks the creative potential of many whose agency is stifled by the uneven power dynamics ingrained in the society.

1 The Constitution of the Republic of South Africa, 1996, Preamble.

2 S v Makwanyane and another 1995 (3) SA 391 (CC) 261. 


\section{Introduction}

The South African Constitution is novel ${ }^{3}$ its express and implicit provisions, timbre, ethos and the general formulation is permeated by a transformative agenda. The Constitution leans toward a transformative jurisprudential trajectory. ${ }^{4}$ It is a vehicle on which the prospects of restructuring South African society hinges on.

The foremost '... objective of the Constitution is that it facilitates the transformation of South African society'. 5 The South African Constitution has been lauded as a transformative tool which marks a complete departure with the past. ${ }^{6}$ It is not a coincidence that the South African Constitution has a pervasive transformative trope if one bears in mind the racist, divisive and structurally oppressive apartheid context from which it sprang against. The Constitution is reactionary and remedial in its character. I aver that apartheid's structural edifice of seclusion and inequality is the mischief the South African Constitution strives to correct.

Although the Constitution contains a futuristic element of mapping a just and equitable society founded on the supremacy of the Constitution, ${ }^{7}$ it also has '... a a backward-looking aspect, the Constitution aims to facilitate the transformation of society by setting right the wrongs of the past.' 8 The foregoing is buttressed by the following observation:

Our Constitution recognises that decades of systematic racial discrimination entrenched by apartheid legal order cannot be eliminated without positive action being taken to achieve that result. ${ }^{9}$

The Constitution embodies a trenchant commitment and promise to free the creative potential and harness the potential of all citizens but especially those whose voices have been muzzled by apartheid's years of ideological and material seclusion. The Constitution is also markedly different from other progressive constitutions such as that of the United States of America because of its comprehensive Bill of

3 Constitution (n 1).

4 For more on the transformative direction that the Constitution takes, see S Liebenberg 'South Africa adjudicating social rights under a transformative Constitution' in M Langford (ed) Social rights jurisprudence emerging perspectives in international and comparative law 2008.

$5 \quad$ Liebenberg (n 4) 75.

6 Makwanyane (n 2) para 261

7 Constitution (n 1) Section 2.

$8 \mathrm{~S}$ Liebenberg Socio-economic rights adjudication under a transformative constitution (2016) 25.

9 Bato Star Fishing (Pty) Ltd v Minister of Environmental Affairs and Tourism and others 20047 BCLR 687 (CC). 
Rights which contains justiciable civil, political and socio-economic rights such as the right to housing and education. ${ }^{10}$

In this article, I intend to focus on the notion of human agency. I argue that the ideologically laden concept of human agency should constitute an ideological and jurisprudential frame from which socioeconomic rights as enshrined in the Constitution should be construed. I seek to ground my submissions on human agency on theoretical perspectives which challenge the present uneven structures of power in South Africa. This essay draws from a multiplicity of disciplines such as Law, Social Sciences and Development Studies.

Such a multipronged disciplinary approach to the notion of human agency furnishes a fresh jurisprudential angle to the manner in which socio-economic rights in the Constitution have been construed. The essay is alive to the March 2018 World Bank Report which sets out in clear detail the inequalities that stifle the agency of the majority of the population in South Africa. ${ }^{11}$ The essay will reconceptualise the notion of human agency in view of socio-economic rights in the South African Constitution. The philosophical contours which undergird my formulation of the concept of human agency will be discussed. In the end, I will provide some reflections regarding the way forward in an effort to engender agency on many South African citizen.

\section{Conceptualising the notion of human agency}

I argue that the notion of human agency is the philosophical trope that permeates the Constitution. The notion of human agency, in its proper formulation, must inform the nation's policy.

The term agency generally carries the thought of being in charge, empowered, and endowed with the ability to participate in the affairs of life as a complete citizen. The foregoing formulation of the notion of human agency carries the implication that a person who has agency vindicates his worth or dignity through his engagement with the environment and engages with the world and everyone from a point of an active participant in the processes of life. I should mention that representative and participatory forms of democracy which the Constitution contemplates remain a mirage if it is not grounded in an economic base. Participation and agency require material and intellectual goods or resources to facilitate involvement. This notion finds support in the apt submission of JE Stewart '... for democracy to be realistically attainable it had to be located in a sound and

10 Constitution (n 1) Section 8 and section 38 thereof on the various groups of litigants who have locus standi to adjudicate their rights.

11 'Overcoming Poverty and Inequalities in South Africa an Assessment of Drivers, Constrains and Opportunities' http//www.Worldbank.org/curated/en/5304815 21735906534/pdf/124521-REV-ous.sc (accessed 8 July 2018). 
independent economic base'. ${ }^{12}$ The constitutional jurisprudence of the courts, especially the Constitutional Court, has stressed the centrality of participation in all facets of life. In Doctors for Life International $v$ Speaker of The National Assembly and others ${ }^{13}$ the Constitutional Court spelled out the thrust of participation or agency as embodied in the Constitution:

The participation by the public on a continuous basis provides vitality to the functioning of representative democracy. It encourages citizens of the country to be actively involved in public affairs, identify themselves with the institutions of government and become familiar with the laws as they are made. It enhances the civic dignity of those who participate by enabling their voices to be heard and taken into account. ${ }^{14}$

The above buttresses my submission to the effect that agency as embodying notions such as dignity and participation, runs to the heart of the South African constitutional scheme and is the nexus between equality, human dignity and the quest for a vibrant democracy as borne by the following quotation:

Participatory democracy is of special importance to those who are relatively disempowered in a country like ours where great disparities of wealth and influence exist. ${ }^{15}$

The concept of human agency from a transformative jurisprudence standing, ushered in by a supreme Constitution in South Africa contests structural inequalities that lie deep within the South African society. The foregoing notion is alive to the dialectical relationship that exists between human agency and the material conditions in which the majority of people in South Africa find themselves. This formulation of human agency challenges liberal conceptions which view human agency as a static concept.

On the contrary, the notion in its proper construction is concerned with people in their societies in a process of engagement and renegotiating the conditions which impact on their ability to participate meaningfully in all aspects of life, especially materially. This resonates well with the following submission:

Negotiations between individuals and their perceived (social and physical) environments and also between people are always informed by relations of power. Not only structures and actors act upon one another, but also the production of agency in various domains of society

12 J Stewart 'Zimbabwe: formal structures for sustainability and democracy versus grounded reality' in G Hollands \& G Ansell (eds) Winds of social change civil society interaction with the African state proceedings of multilateral workshops on good governance, sustainable development and democracy. Gaz, Austria 1995Kampala, Uganda 1998 (1998) 76.

13 Doctors for Life International $v$ Speaker of the National Assembly and Others 200612 BCLR 1399 (CC).

14 Doctors for life (n 13) para 115.

15 As above. 
generates different power (im-) balances. In this process, new inequalities are produced and social hierarchies established. ${ }^{16}$

The above quotation is alive to the fact that unequal power relations produce structural inequalities and uneven geopolitical and economic relations. The uneven economic power and economic dynamics in South Africa, owing to historical imbalances and persistent reproduction of the unequal conditions, affect the potential of those marginalised. It is against this background that the South African Constitution and the jurisprudence on socio-economic rights seek to redress the '... trajectories that move out of, mediate or negate these states of being. 17 The concept of human agency thus seeks a jurisprudential trajectory that is embedded in the historical and material context in which the Constitutional provisions especially those that impinge on socio-economic entitlements are construed and applied to facts. This feeds into the scope of Karl's pacesetter thrust on transformational constitutionalism which bears quoting:

[A] long-term project of constitutional enactment, interpretation and enforcement committed (not in isolation, of course, but in a historical context of conducive political developments) to transforming a country's political and social institutions and power relationships in a democratic, participatory, and egalitarian direction. Transformative constitutionalism connotes an enterprise of inducing large-scale social change through nonviolent political processes grounded in law. ${ }^{18}$

There is a sharp resonance with Klare in the bulk of the Constitutional Court's jurisprudence. ${ }^{19}$ Klare's conception of a transformative constitution fits clearly into the notion of human agency. His formulations measure the transformative nature of a constitution using the yardstick of how it enables the previous marginalised to participate or to have agency, especially in the economic sphere. Klare buttresses the foregoing in the sense that his conception is steeped in law, politics and economics and how these should be analysed within the historically-specific circumstances of a people, in this case, South African society.

The marginalised, as shown by the quotation above, are especially the ones who must, through meaningful and substantive steps by the state, be empowered to find their voice that has been muzzled by dispossession and want. The historically disempowered should be empowered to creatively express themselves as active participants in all areas of life, especially in the economic space. It is the desperate,

$M$ de Bruijin, R van Dijk and J Gewald 'Social and historical trajectories of agency in Africa: An introduction' in M de Bruijin, $R$ van Dijk and J Gewald (eds)Strength beyond the structure social and historical trajectories of agency in Africa (2007) 7.

17 De Bruijin (n 16) 6.

18 K Klare 'Legal culture and transformative constitutionalism' in S Liebenberg; (n 8)24.

19 See Makwanyane (n 2) para 261 and Bato star (n 9) para 73 and 74. 
the vulnerable, termed as people inhabiting 'at the bottom of the world economy..." 20 by $\mathrm{P}$ Collier who, through the provision of decent housing, respectful amenities, access to relevant education and skills, among other pertinent initiatives, must regain their agency through active participation.

It must be note that the engendering of meaningful agency does not only presuppose the state doing things for the disparate such as social welfare. Engendering agency substantively connotes the notion of people gaining the means of production such as land, material wealth, requisite skills and capacity to do things themselves. When the vulnerable gain their capacity to alter, especially materially, the conditions or the circumstances of their being they could be said to have acquired agency. On the other hand, a conception of development and agency that only stresses what the government can do to the disparate is limited and impoverished. The Constitution contemplates people who have access to the means of production, who have the capacity to alter and renegotiate their conditions of existence. ${ }^{21}$ Ndulo's quotation strikes a similar cord:

The best form of government is that which tends to foster in the people such qualities as initiative and inventiveness, and to steady improvement in their overall intellectual and moral qualities, since on these depends in turn the success of government in promoting economic development and the well-being of the society. ${ }^{22}$

It is clear that the role of the government should be creating an even playing ground which enables people who are historically disadvantaged to get traction and to ground their actions in initiative, inventiveness and innovation.

\section{Mapping the contours of the philosophical terrain}

I now focus on mapping the philosophical contours on which my arguments are premised-that is, the theoretical and ideological base which render a perspective to my conception of socio-economic rights formulations.

I ground my understanding of Socio-economic Rights on a metaphorical ideological picture formulated by Moore called Traction. Moore's theoretical perspective is apt to my topic because it is based on the entanglement between history, economic

20 P Collier Wars, guns \& votes democracy in dangerous places (2010) 1

21 The Preamble to the Constitution entrenches the Constitution's commitment to 'improve the quality of life of all citizens and free the potential of each person'.

22 M Ndulo 'Good Governance: The rule of poverty alleviation' in M Ndulo (ed) Democratic reform in Africa its impact on governance and poverty alleviation (2006) 3. 
imbalances and uneven playing field; this grounding resonates with South Africa's circumstances in which disparate people try to ground their agency or traction in 'an uneven geography of power', 33 and where "conditions of possibility of traction shift across uneven landscapes, historical moments, and the differential abilities of specific subjects to establish footholds that gain ground'. ${ }^{24}$ The preceding point is laden with thoughts that it calls for unpacking in the context of South Africa's uneven and slippery power and economic geography.

The World Bank Report (March 2018) on South Africa has laid it bare that South Africa is one of the most uneven countries in the world and much of her problems are deep and structural grounded in history and unequal access to enablers such as education and the means of production. 25 The following statement from the report drives the conception home:

South Africa's structural transformation is well advanced, but factors of production are not always allocated to their most productive use. ${ }^{26}$

The disparate in South Africa fail to gain traction owing to the little or no access to the tools or the enablers of transformations such as a respectable material space. I advance the argument that enabling the poor to get firm footholds on land, clean water, dignifying amenities, sound and relevant education, among other enablers, will tilt the unjust terrain in their favour and enable agency.

Moore's conception falls into the same trope with A Sen's conceptual framework which locates agency within the domain of its symbiotic relationship with freedom of choice in an environment where material goods are distributed evenly. The averment as quoted in S Friedman's critical work on positive duties imposed by all rights runs:

This approach draws on the insights of modern theorists, in particular of Armatya Sen, who see freedom not as the absence of coercion, but as agency, or the ability to exercise genuine choice and to act on the choices. ${ }^{27}$

The formulation by Sen is in sync with the recurring thread of argument in this essay to the effect that agency should be premised on a sound economic base which enables one to make choices and to act on the choices made. The new perspective emerging from the foregoing is that even the idea of participatory and direct democracy in South Africa does not really place substantive choices among the

DS Moore Suffering for territory race, place, and power in Zimbabwe (2005) 281. As above.

World Bank report (n 11) 3.

As above.

27 S Fredman Human rights transformed positive rights and positive duties (2008) 11. 
citizens due to the fact that most people are not conscious of the choices they purport to be making. They lack the real power and the material and political goods to effect informed choices and hence the freedom of many is curtailed and restricted, because if we go by Sen's conception of freedom, freedom exists in the ability or the cogency to make informed choices.

This viewpoint finds favour with the recent unanimous judgment of the Constitutional Court in relation to the nexus between the need for disclosure of political parties and the right to vote to get cogency. In the said case called My vote counts NPC $v$ Minister of Justice and correctional services and another, ${ }^{28}$ the Constitutional Court shed light on the right to vote as enshrined in Section 19 of the Constitution and its relationship with Section 32 which provides for the right to information and which enjoins parliament to make laws with regard to access to information. What is pertinent about the said case is the reasoning of the unanimous court regarding the right to vote which is an exercise of participatory democracy. The court held that if the information regarding the funding of political parties is not reasonably made available then the right to vote is meaningless and impoverished. It will remain an elusive dream. What is interesting and which bear on the issue of human agency is what the court said regarding choice:

Choice is of its own a loaded concept. And much more is required of a choice-maker if the choice is to be made is political in character and affects important national interests. The gravity of the choice is more pronounced in relation to the right of an adult citizen to participate or vote in the elections for any 'legislative body'. ${ }^{29}$

Choice, is at the heart of human agency. The choice, however, must be informed and ought to be engendered by having access to information. This requires material and intellectual goods as explained by the World Bank report:

As people gain middle-class status, they tend to accumulate savings and acquire secondary and tertiary education investments in the future. Members of the middle class are likely to support accountable government and rule of law. ${ }^{30}$

The point is that the ability to act and take charge is premised on sound social, material and intellectual goods. That, in turn, result informed choices economically and politically.

It is clear that the concept of human agency should be understood in a complete sense involving the totality of a person's resources, mainly economic, to adequately get traction in a given society. This 
speaks to Marx and Engels who ground an economic base as a sine qua non of political, social and cultural participation as evidenced by their quotation which follows as gleaned from R Moyana's book:

The class which has the means of production at its disposal, consequently also controls the means of mental production, so that the ideas of those who lack the means of mental production are on the whole subject to it. The ruling ideas are nothing more than the ideal expression of the dominant material relations which make the one class the ruling one, therefore, the ideas of its dominance. ${ }^{31}$

What is pertinent from the above is that to establish agency among the disparate, vulnerable and dispossessed, their material conditions must be improved. A clear causal nexus exists between material force and cultural and intellectual force. The dominant voices in every epoch are those of the structural powers who have access to economic goods and the corporate global media machinery at its beck and call. The amalgamation of the philosophical underpinnings I have delved into amount to one point; agency is the sum-total of the goods that a person has and the enabling conditions that result from such a base that emplace participation and initiative. This frame of thinking is also supported by Fredman who problematises the superfluous distinction between negative rights (as in civil and political rights) and positive rights as encapsulated in Socio-Economic rights. Her quotation is illuminating:

Transforming human rights, therefore, requires a greater focus on positive duties to which all human rights give rise. It entails moving beyond artificial distinctions between civil and political rights, to recognising that all rights give rise to the whole range of positive duties. $^{32}$

\section{Socio-Economic rights in South Africa}

\subsection{A brief history}

The Constitution was meant to break away from a painful past of exclusion of the majority of people for the benefit of one race. It is instructive, with the aim of establishing a context in which to locate the necessity of Socio-Economic rights in South Africa, to sketch a brief background of the alleged exclusion dispossession of the majority.

South Africa's past is tainted by the sceptre of racism which still remains buried in the economic and social structures and ingrained in the hearts of a considerable number of people, though formally, steps

31 R Moyana Reading our past: an historical study of the white authored novel in Zimbabwe CA 1890 to 1914 (2017).

32 S Fredman (n 27) ix. 
have been taken to address the matter. When the National Party came into power in 1948 (although the indigenous have already been colonised and dispossessed dating back from 1652) racism was taken to a new level by the introduction of its ideology of 'separateness'. 33 That is the heartland of Apartheid in which black people mainly and other disadvantaged such as Indians and other enclaves of Orientals in South Africa, were discriminated upon and treated as low class citizens as they were driven into the margins of social and political life.

Practically all whites had access to the material goods, the best residential areas, amenities, access to education and sophisticated skills, and access to political resources and power. The situation (as South Africa was, and to some extent still is) is aptly captured in the following quotation:

South Africa cannot be described as a democracy. It is more aptly described as pigmentocracy in which all political power is vested in a white oligarchy, which is in turn controlled by an Afrikaner elite. ${ }^{34}$

I submit that although it appeared that the apartheid ideology was influenced by race and bigotry, its main object was economic hegemony. From the Marxian perspective delved into earlier on as a philosophical premise on which this essay proceeds from, the economic basis is the foothold on which ideological superstructure of racial exclusion was premised on. The feelings and perceptions of white superiority were bolstered by an actual superiority in the ownership of the means of production. It is when we understand the philosophy of racism and apartheid as an ideology grounded in economic accumulation, that we begin to confront the embedded structures of racism and strive to gain footholds that enable many of the marginalised to gain traction in the true and substantive sense. That is when the South African notion of a constitutional democracy will begin to have a substantive hue.

The struggle for freedom in South Africa, as elsewhere in the continent, was grounded in a quest for freedom and economic and material emancipation. Emancipation and the improvement of the squalid conditions in which many South Africans found themselves. The freedom fighters contemplated freedom in its substantive sense in which many would be able to participate in all the realms of life and in which bread and freedom would be complementary to each other in the symbiosis of agency as succinctly captured by Sach's averment:

Our experience, in fact, demonstrates that instead of undermining each other, freedom and bread were interrelated and interdependent. ${ }^{35}$ 
It is now 24 years after the dawn of democracy in South Africa. Several steps have been taken to address the economic imbalances in South Africa and the nation prides itself as having one of the most enviable and progressive constitutions in the world, yet the triad of uneven economic conditions, inequality, and unemployment continue to batter the fortunes of an economically well-endowed adolescent democratic country in the tip of the Southern African part of the continent.

\subsection{The South African constitution and Socio-economic Rights}

Chapter 2 of the South African Constitution, ${ }^{36}$ commonly known as the Bill of Rights, is a compendium consisting of a myriad of rights entitlements and is the bedrock of the democratic space in South Africa. It is the 'cornerstone of democracy in South Africa'. 37 The said compendium of rights contains a panoramic sphere of entitlements which are justiciable before a competent court of law. The Bill of Rights contains what has been termed civil and political rights such as the rights, to equality, ${ }^{38}$ to human dignity, ${ }^{39}$ life, ${ }^{40}$ and freedom and security of the person. ${ }^{41}$

These rights are couched as absolute rights and they are not subject to internal qualifiers that postpone their enjoyment, they are perceived as immediately capable of realisation. They impose, as the dominant conception, which I problematise as faulty thinking, negative duties mainly on the state to leave the individual on his own to enjoy his or her freedom unencumbered by encroachment as a free moral agent capable of steering his or her course of life to freedom. The compendium of rights also contains what are often called SocioEconomic Rights which, like all rights, (in a true and substantive exegesis) impose positive duties on the state for their gradual realisation. These rights are subject to internal qualifiers which subject them to a gradual realisation and enjoyment. Their enjoyment is linked to the material resources that the state has, and in its reasonable discretion, sees fit to deploy toward their realisation. These rights, among others, contain entitlements to: property, ${ }^{42}$ have access to adequate housing, ${ }^{43}$ Healthcare, food, water and social security, ${ }^{44}$ and Education. ${ }^{45}$

\footnotetext{
Constitution (n 1) Chapter 2.

Constitution (n 1) Section 7.

Constitution (n 1) Section 9.

Constitution (n 1) Section 10.

Constitution (n 1) Section 11.

Constitution (n 1) Section 12.

Constitution (n 1) Section 25.

Constitution (n 1) Section 26.

Constitution (n 1) Section 27.

45 Constitution (n 1) Section 29.
} 
Socio-Economic Rights seek to create enabling conditions that result in the attainment of human dignity and should be located within the context of an attempt to bridge and redress the past. They seek to emplace traction on the previously disadvantaged and attempt to confront structural inequality and nip at the bud the conditions which perpetually breed the same outcome; the conditions of illiteracy or poor skill, dispossession and inequality.

\subsection{Breaking away from a befuddled conception of rights}

I have already indicated by discomforts and reservations with a formal and befuddled conception of human rights into either those which give rise to positive duties or those perceived as giving rise to negative duties. That purported differentiation is an ill-conceived formulation which is intellectually insipid. I am in favour of the plausible conception by Friedman who avers correctly that:

The first step is to recognise that there are important interactions between the two sets of rights. Without basic socio-economic entitlements, civil and political rights cannot be fully exercised. ${ }^{46}$

Fredman's thrust of argument is alive to the interwoven nature of all rights in enabling human agency and sees all rights, as complementary to each other. The foregoing conception also treats all rights as in the same plane and giving rise to positive duties. The Constitutional Court has hinted to the matter in the recent My vote counts case where the right to make a political choice was tied to the right to access to information about the private funding of political parties. ${ }^{47}$

The judgment acknowledges the nexus between political participation and economic agency. This is buttressed by the following insightful observations by Liebenberg in which she avers that a plausible conception of all human rights 'entails a critical examination of economic and social institutions and relationships to ascertain their impact on the participation of disadvantaged groups in all spheres of our young democracy'. ${ }^{48}$ The cogency of Liebenberg's intellectual thrust lies in the realisation of the inseparability of rights and in the awareness that the end of all human rights is to enable traction in the form of participation in all areas of life by those disadvantaged and disparately poor.

I have attempted to show the nexus between agency and rights. Further to show the illusory and futility of attempting to classify rights into generations especially within the context of South Africa because, the entanglement of the structural inequalities require a holistic approach. Otherwise, many will continue to have an empty 
shell or a mere formality of political freedom without a material substance attached to it.

\subsection{On the adjudication of Socio-economic rights in the South African Courts: the Grootboom case}

Adjudicating socio-economic rights is not an easy task that is placed on the shoulders of the nation's judiciary. Theirs is a difficult task of trying to juggle competing justiciable claims or entitlements in an environment of modest and at times, scarce material means. The courts are also always alert to the need to avoid encroachment into the domain of other arms of the state. The judiciary is keenly aware also of its institutional modesty when it comes to matters of allocation of resources. The question of economic rights also straddles, more often than not, in the domain of politics and sentiments are often high. The task of the judiciary then is to stay clear of unnecessary encroachment into the institutional competence of the other arms of the state, unless constitutional necessity bids them along such a terrain. In figurative language, their task is often lonely and they often have to swim against the tide of sensationalism and the mistake of acquiescing to the pressure of the politicians on the one hand, and the pouring demands of the civil society and the drowning clamour of the tired and impoverished masses on the other hand.

Government of the Republic of South Africa and others $v$ Grootboom and others is a seminal case in socio-economic jurisprudence in South Africa and the world over. ${ }^{49}$ It is a milestone in adjudication of socio-economic rights jurisprudence. The case buttressed that these socio-economic rights are not mere directives in the context of South Africa but are justiciable by the courts. The case also supported the conception of rights which views all rights as 'inter-related and mutually supporting'. 50 Grootboom also touched on the tightrope that the judiciary had to tread in trying to preserve the institutional integrity of each relevant arm of the state. 51

Grootboom centred on Section 26 of the Constitution. Specifically it drew attention to the extent to which it is enjoined by the Constitution to take significant measures toward the gradual realisation of the right to housing. The case focused on the plight of the desperate homeless people residing in the margins of the society without meaningful access to the national cake in the form of decent housing, respectful amenities, and land. The 'Grootbooms' in this 200011 BCLR 1169 (CC).

50 Grootboom (n 49) para 23.

51 Grootboom (n 49) para 41. 
case, to employ an analogy, had their fragile houses demolished in their absence. They desperately moved to a new area where they were also required to move away from because it was private property. The elements were at their most hostile and inclement and they sought interdictory relief in the high court which was successfully upheld. The matter then wound up to the Constitutional Court on appeal.

The Constitutional Court using the reasonable test standard, found the measures taken by the government in addressing housing problems as falling foul of the constitutional muster of reasonableness. This because it failed to have measures in place to address the housing needs of those who are most desperate. ${ }^{52}$ One of the plausible findings of the court is its grounding of the nexus between human dignity and the provision of adequate decent housing. 53

Where I have difficulties with the judgment of the Constitutional Court, is its refusal to adopt what has been termed the minimum core. That standard imposes a minimum threshold on the state to fulfil in the progressive realisation of socio-economic rights. The Court's major ground of departure from the minimum threshold, it averred, lay in the impossibility of determining the minimum threshold 'without first identifying the needs and opportunities for the enjoyment of the right'. ${ }^{54}$ I argue that the ethos of the Constitution and the substantive need for equality and the need to create a favourable traction among the disadvantaged offers a threshold in which to view the reasonableness of the government's action.

The Constitution contemplates an inclusive society where previously marginalised groups are enabled to fully participate in all spheres of life. The standard, in simple, lies in assessing whether the poor will be able to participate in a dignified manner, and to a reasonable level, in the affairs of life. Viewing the provision of the access to socio-economic rights using the threshold of human agency will yield a different result. The merits of each case will then have to be viewed differently. Of course, that may offend legal certainty, but the benefits would outweigh the impediments. 


\section{Toward engendering human agency: Key enablers}

\subsection{The land issue}

No other issue is evocative as the issue of land. In South Africa, just like what took place in Zimbabwe, the question of land tends to straddle into the domain of race. The issue divides people mainly along the lines of race and class. In my premises, I used the traction metaphor which I said the marginalised are failing to establish firm footholds of traction. The main problem of the poor is their inability to access the chief means of production-land. Madeley expressly articulates the conditions in which the poor find themselves:

Many of the poor are either landless or have tiny plots, with poor soil ... many are poorly educated and in poor health, their housing and shelter are meagre, they have few resources at their command. They may go hungry even when food in the area where they live is relatively plentiful. Their poverty means that they do not have the land to grow the food they need, nor the money to buy food. The life expectancy of the poor is short and shortening in some countries. Many are jobless and voiceless; many have their livelihoods damaged by the increased severity of environmental conditions. ${ }^{55}$

Madeley, touches on the structurally-entangled existence of the poor. The poor are mainly poor because they lack the means of production chiefly land. This is what renders the land question in South Africa an unavoidable one, because it is at the centre of the Constitution's commitment to redress the uneven terrain of the past. However, I must point out at this juncture that, while it is desirable and inevitable to restore the dignity of the disadvantaged by enabling access to the means of production, the issue has to be dealt with in a calm, phlegmatic and considered manner because it has the inadvertent problem of further disadvantaging the poor if not handled carefully.

The question of bankable titles given to the previously advantaged has to be considered also. Land without proper titles would be of little benefit because it is ineffective for the purposes of collateral. The needs of the market also ought to be considered. The question of land has to be dealt with in a manner that does not offend the rule of law. I also make the submission that the poor of resources have to be gathered to equip the new farmer before the process of appropriation; this will, no doubt, include the skills and technical know-how. The government must also leave farms held by White farmers as they are critical for the furtherance of food security in the world's poor (2008) 6. 
land. It is a tough conundrum of contemplating land expropriation without compensation whilst at the same time contemplating attracting foreign investment. A delicate balance has to be found.

I must also mention the potential pitfall of elite capture of the land by those in control. The land must be redistributed in a manner that is free from the elite capture of the resources and focuses more on the disadvantaged and desperate. Having noted the constraints and cautions, it bears mention that access to land is linked to granting agency to the disadvantaged in South Africa. This is supported by the following quotation:

Through a redistribution of land and other resources, agrarian reform seeks to restructure and democratise the oppressive relations of production which constitute the agrarian question. ${ }^{56}$

From the submissions tendered thus far, it is a irrefutable proposition that land is at the heart of the nexus between the means of production and human agency. I now turn to address the issue of education as another enabler.

\subsection{Access to relevant education}

Access to education is one of the key enablers of agency which the Constitution contemplates. Access to relevant skills is at the heart of empowerment. Education that is relevant and practical gives a pertinent voice to the disadvantaged. The education, however, should have a bias toward the attainment of skills. It should make South Africans stake a proud place among the citizens of the globe as equals.

Smith adds her voice on the importance of a pragmatic education which grounds theory and practice when she submits 'The pedagogical implication of this access to alternative knowledge is that they can form the basis of the basis of alternative ways of doing things'. ${ }^{57}$ The nature of education, which is at the heart of emplaced agency, is built on a pedagogical framework that is multidisciplinary especially within the field of law. A pedagogy which is aware of the past whilst not bound by it, and exceedingly forward-looking. Education should strive to create new tools in the form of theoretical underpinnings which are grounded mainly in African Philosophy. The crux of my argument is that we should harness theoretical tools that speak to our specific condition as Africans.

56 L Tshuma A matter of (In) justice: Law, state \& the agrarian question in Zimbabwe (1997) 2-3.

57 LT Smith Decolonising methodologies research and indigenous peoples (1999) 34. 


\section{Concluding reflections}

This essay has focused on socio-economic rights in South Africa from a philosophical notion of human agency. My argument is that if human agency is used as a jurisprudential yardstick which the Constitution strives toward, better results will emerge. The main thread which permeates the entire essay is that material goods and human participation and agency are complementary aspects and that is what the socio-economic provisions in the Bill of Rights of the Constitution contemplates. The essay has rejected as befuddled thinking, a conception which seeks to group rights into duties which are either positive or negative.

One may think of the right to vote which is mainly conceptualised as a right which is immediately enjoyed by every adult citizen. However, without access to information, adequate education and decent amenities, the voter will not participate and enjoy the right in a substantive sense. The essay has focused on land and education as key enablers of agency, among other tools of inculcating agency. These are simply reflections of a law student. 